\title{
The Feminine Ending -at as a Diptote in the Qurānic Consonantal Text and Its Implications for Proto-Arabic and Proto-Semitic
}

\author{
Marijn van Putten \\ Leiden University \\ m.van.putten@hum.leidenuniv.nl
}

\begin{abstract}
This paper examines the feminine ending - at in the Qur'ānic Consonantal Text. It argues that from the Qurānic Consonantal Text, and various data of comparative linguistic evidence, it is likely that the language of the Qurānic Consonantal Text goes back to a variety of Arabic where the feminine ending was treated as a diptote. It is moreover argued, that this feminine ending was likely also diptotic in Proto-Arabic.
\end{abstract}

\section{Keywords}

Arabic, Qur’ānic Consonantal Text, historical linguistics, feminine ending, diptotes

\section{Résumé}

Cet article examine la terminaison du féminin -at dans le texte consonantique du Coran. Il soutient qu'à partir du texte consonantique du Coran et de nombreuses données de linguistique comparée, il est probable que le texte consonantique du Coran remonte à une variété d'arabe dans laquelle la terminaison du féminin était traitée comme un diptote. En outre, il est soutenu que cette terminaison du féminin était probablement aussi diptote en proto-arabe.

\section{Mots clefs}

Arabe, texte consonantique du Coran, linguistique historique, terminaison du féminin, diptotes 


\section{Introduction}

This paper aims to examine the features of the feminine ending of the language of the "Qur'ānic Consonantal Text." There is a disconnect between the orthography of the Qur'ān and the Classical Arabic pronunciation, and this has been widely recognized (e.g. by Chaim Rabin, ${ }^{1}$ Werner Diem ${ }^{2}$ and Gerd-Rüdiger Puin $\left.^{3}\right)$. For this reason, it is worth examining what the Qurānic Consonantal Text itself can tell us about the language of the Qurān, rather than relying on the text as reflected in the reading traditions and the many diacritical marks that mark features such as short vowels, nūnation, the hamza and occasionally even long vowels, which are later additions to the text.

While the concept of the Qurānic Consonantal Text is quite similar to the rasm, the undotted consonantal skeleton of the Qurānic text, there is one important distinction. While the different reading traditions occasionally disagree on minor points in the consonantal dotting of the rasm, the enormous amount of consensus between the reading traditions suggests a fairly accurate transmission in terms of lexical content of the Qurān. The almost completely undotted text, as we find them in the earliest Qurānic documents, ${ }^{4}$ allows for a virtually endless amount of vastly different readings. However, we do not find great amounts of competing readings of the Qurān. For this reason, when discussing the Qurānic Consonantal Text in this paper, I assume that the consonantal dotting as we find it in the modern Cairo edition of the Qurān is essentially correct. ${ }^{5}$

1 Chaim Rabin, "The Beginnings of Classical Arabic," Studia Islamica, 4 (1955), p. 19-37.

2 Werner Diem, "Some Glimpses at the Rise and Early Development of the Arabic Orthography", Orientalia, 45 (1976), p. 251 ff.

3 Gerd-Rüdiger Puin, "Vowel letters and ortho-epic writing in the Qur'ān", in New Perspectives on the Qur'ān: The Qur'ān in its historical context 2, ed. Gabriel Said Reynolds, London-New York, Routledge ("Routledge studies in the Qur'ān"), 2011, p. 147.

4 François Déroche, Qur'ans of the Umayyads: A First Overview, Leiden, Brill ("Leiden studies in Islam and society", 1), 2014, p. 20.

5 This assumption is given strength by the fact that, even though early Qur'ān codices such as the Codex Parisino-Petropolitanis discussed by Déroche ibid. are almost completely undotted, the few times that consonants are dotted, we do not find disagreements with the Cairo edition. 


\section{Feminine Endings in the Qur'ānic Consonantal Text}

The productive feminine ending $-a t(u / a / i-n),{ }^{6}$ is normally spelled in the Qur'ān as $\alpha^{-7}{ }^{7}$ This spelling, although it is often considered to reflect the pausal pronunciation, actually violates the pausal rules that normally operate on the Arabic of the reading traditions. These rules can be summed up as follows:

$$
\begin{aligned}
& { }^{*} a n>\bar{a} \\
& { }^{*} u / i(n)>\emptyset \\
& { }^{*} a t>a h^{8}
\end{aligned}
$$

Following these pausal rules the following pausal paradigm for the indefinite feminine of ummat-"people" would be expected:

6 In recent years, some controversy has developed over whether Proto-Arabic had case at all. This has been argued most notably by Jonathan Owens, A Linguistic History of Arabic, Oxford-New York, Oxford University Press ("Oxford linguistics"), 2006. In light of the Semitic comparative evidence, as well as clear evidence for Pre-Islamic and Pre-grammarian early Islamic varieties of Arabic that have functioning case systems, this position is impossible to uphold. For a discussion on Arabic case, see Ahmad Al-Jallad and Marijn van Putten, "The Case for Proto-Semitic and Proto-Arabic Case: A reply to Jonathan Owens," Romano-Arabica, 17 (2017), p. 87-117. Some forms of case are overtly present in the Qurānic Consonantal Text, e.g. the indefinite accusative, the sound masculine plural, the dual and the "five nouns." As such, it cannot be doubted that a case variety is ancestral to the language of the Qurānic Consonantal Text. This is not to say that case was still fully functional as it is in Classical Arabic or identical to it. Marijn van Putten and Phillip Stokes, "Case in the Quran," forthcoming, argue that the final case vowel system was much reduced in the language of the Qur'ānic Consonantal Text.

7 The exception is the common spellings of the construct feminine with رحت الله شجرت الزقوم (The mercy of God) and Kor 37, 62 (The of Zaqqūm), making up about $22 \%$ of all feminine ending constructs in the Qur'ān. Early Qurānic codices, even if they do use consonant signs, never seem to distinguish the $t \bar{a}$ marbūṭ from a regular final $h \bar{a}$. We will not make this orthographic distinction either.

8 There can be no doubt that the pronunciation of the feminine ending is - $a h$, and only later shifted to $-a$, as it is now often pronounced in Modern Standard Arabic. Many modern Arabic dialects still retain - $a h$ in this position, for example see Otto Jastrow and Wolfdietrich Fischer, Handbuch der Arabischen Dialekte, Wiesbaden, Harrassowitz ("Porta linguarum orientalium. Neue Serie", 16), 1980, p. 121. Moreover, -ah clearly does not rhyme with final - $\bar{a}$ in the Qurān, while it does rhyme with the third person masculine pronominal suffix e.g. Kor 74, 55 dakarahū. 


\section{Nominative *ummatun $>$ ummah \\ Genitive *ummatin > ummah \\ Accusative *ummatan $>$ **ummatā}

As can be seen in the table above, one would expect the indefinite form of the feminine ending to have orthographically two forms, a nominative/genitive $\alpha$ and an accusative ***. However, such a spelling for the accusative is not attested in the Qur'ānic Consonantal Text. Several researchers have attempted to explain this problem.

Harris Birkeland ${ }^{9}$ suggests that nūnation was lost on the feminine ending -at before the masculine ending, thus yielding different result. However, this solution is totally ad hoc.

Due to the mismatch in spelling and pronunciation, Wolfdietrich Fischer ${ }^{10}$ suggests that the spellings of the Qur'ānic Consonantal Text orthography cannot represent the "pausal spellings" of the noun with endings *-atu/i/a(n), as the indefinite accusative was pronounced /-ah/ in pause, e.g.

$\begin{array}{lll}\text { Kor 74, } & 50[\ldots] \text { mustanfiratun } & \text { /mustanfirah/ } \\ & 51[\ldots] \text { qaswaratin } & \text { /qaswarah/ } \\ & 52[\ldots] \text { munaššaratan } & \text { /munaššarah/ } \\ & 53[\ldots] \text { al-'ähirata } & \text { /al-'āhirah/ } \\ & 54[\ldots] \text { tadkiratun } & \text { /tadkirah/ } \\ & 55[\ldots] \text { dakara-hū } & \text { /dakarah/ } \\ & 56[\ldots] \text { al-maġfirati } & \text { /al-mag்firah/ }\end{array}$

For this reason, Fischer"1 concludes that already in "Old Arabic" (including the language of the Qurānic Consonantal Text), the feminine ending was $-\bar{a}$ in context and - $a$ h in pause, whereas the construct feminine was pronounced -at. He however provides no explanation how an original Old Arabic form *atu/i/ $a(n)$ would have become $-\bar{a}$, nor why this $-\bar{a}$ would become - $a h$ in pause, while, e.g. the $\bar{a}$ of Zakariyyā (Kor 19, 2) does not. Fischer's solution, then, raises more questions than it answers.

9 Harris Birkeland, Altarabische Pausalformen, Oslo, I Kommisjon Hos Jacob Dybwad, 1940, p. 97.

10 Wolfdietrich Fischer, "Silbenstruktur und Vokalismus im Arabischen," Zeitschrift der Deutschen Morgenländischen Gesellschaft, 117 (1967), p. 54.

11 Ibid., p. 58. 
In a lengthy footnote Joshua Blau ${ }^{12}$ attempts to alleviate the problem of the unusual pausal pronunciation of -at-an:

[I]t can easily be explained by analogy, rather than by sound shift. It seems that the pausal indeterminate accusative after tâ marbûta was adapted to the pausal indeterminate nominative/genitive on the one hand, and to the pausal determinate forms on the other [...]. The reason that this adaptation occurred in these nouns rather than in others, seems to be that in them the difference between the pausal indefinite accusative and the other forms was greater than in other nouns. In a word like malik 'king' the pausal indefinite accusative was malikâ, as against the pausal indefinite nominative/definite accusative form malik, the opposition being expressed by â: zero. In a noun like malikat 'queen', however, the pausal indefinite accusative should have been *malikatâ as against malikah in the other cases, the opposition being expressed by -atâ: ah. Because the pausal accusative was too different, it was adapted to the other cases, and thus malikah became the general pausal form.

This explanation is also ad hoc and does not apply to other asymmetries found in the nominal system. The alternation between -at and -ah is also attested in feminine nouns when followed by pronominal suffixes, and there the alternation between $t$ and $h$ has never been a motivation to spread one of the two by analogy. Moreover, the language of the Qurānic Consonantal Text does not seem to have a problem with differences between the indefinite nominative/genitive and indefinite accusative pausal forms other than just $\bar{a}$ : zero. Final weak nouns like $h \bar{a} d i n$ (guide), for example, display a pausal indefinite nominative/genitive $h \bar{a} d^{13}$ versus a pausal indefinite accusative hādiya a, i.e. a contrast iyā: zero. This alternation was not felt to be disturbing enough to be corrected to a general $h \bar{a} d$ in all indefinite pausal cases. Therefore, there seems to be little reason to assume that this were true for the ending -at-.

12 Joshua Blau, "The Beginnings of the Arabic Diglossia. A study in the origins of Neoarabic," Afroasiatic Linguistics, 4/4 (1977), p. 186-187, footnote 62.

13 This is different from Classical Arabic grammar, which lengthens the vowel in pause for nouns like this, e.g. qādin > qā dì \# Wolfdietrich Fischer, A Grammar of Classical Arabic, transl. from the German by Jonathan Rodgers, New Haven-London, Yale University Press ("Yale language series"), 2002, §57c. This is not the case in the Qurān, e.g. hädin occurs in āC-rhyme five times in the Qurān (Kor 13, 7; 13, 33; 39, 23; 39, 36; 40, 33) confirming that it was pronounced $h \bar{a} d$ in pause. 
Instead, I wish to suggest another solution, namely, that the language of the Qurānic Consonantal Text had a diptotic ${ }^{14}$ feminine ending -at- rather than a triptotic one as found in Classical Arabic. Diptotes in the indefinite do not take nūnation and as a result, all case endings would drop off in pause and yield the attested result:

$\begin{array}{ll}\text { Nominative } & \text { *ummatu }>\text { ummah } \\ \text { Genitive } & \text { *ummata }>\text { ummah } \\ \text { Accusative } & \text { *ummata }>\text { ummah }\end{array}$

Assuming that nouns with the -at ending were diptotic rather than triptotic in the language of the Quraanic Consonantal Text solves the problem of the indefinite accusative. In support of such a reconstruction, we find examples of just this situation in several modern Arabic dialects of Yemen and Saudi Arabia.

Different from other Arabic dialects, these dialects retain reflexes of nūnation on indefinite nouns. ${ }^{15}$ The im-Matțah dialect of the Sa'dah region has an indefinite marker -in, whereas the southern part of Tihāma has - $u$, and the Tihāma on the northern border of Yemen has -un. ${ }^{16}$

14 Diptotic should be taken here to mean mamnū min al-șarf, and does not include the sound masculine plural suffixes (-ūna/-ina), sound feminine plural suffixes $(-\bar{a} t u(n) /-$ $\bar{a} t i(n))$ or the dual ending (-āni/-ayni).

The recent suggestion by Muhammad al-Sharkawi, "Case-Marking in Pre-Islamic Arabic: The Evolutionary Status," Zeitschrift der Deutschen Morgenländischen Gesellschaft, 62 (2015), p. 38-67 that diptotes are an innovation in Classical Arabic cannot be upheld. As has long been recognised, Nabataean Arabic makes a clear distinction between diptotic and triptotic names. Triptotic names receive wāwation whereas diptotic names (mostly names with the $a f^{\prime} a l$-pattern, the $-\bar{a} n$ suffix or the -at suffix) have a zero ending. For a discussion see, Joshua Blau, "Problems of Noun Inflection in Arabic: Reflections on the Diptote Declension," in Biblical Hebrew in its Northwest Semitic Setting: Typological and Historical Perspectives, eds Steven Ellis Fassberg and Avi Hurvitz, Winona Lake-Jerusalem, Eisenbrauns-Hebrew University Magnes Press, 2006, p. 27-32. Therefore, diptotes are clearly part of Pre-Islamic Arabic. Moreover, as will be shown below, Ugaritic and Ancient South Arabian show evidence of diptotes, so they can certainly be reconstructed for Proto-West Semitic.

15 As argued explicitly by Blau, "Problems of Noun Inflection in Arabic."

16 Peter Behnstedt, Die Dialekte der Gegend von Sa'dah (Nord-Jemen), Wiesbaden, Harrassowitz ("Semitica viva", 1), 1987, map 13. 
This indefinite ending was first remarked upon by Joseph Greenman ${ }^{17}$ and further discussed by Theodore Prochazka ${ }^{18}$ for the Tihāma region. It was described in more detail by Peter Behnstedt ${ }^{19}$ who shows that in the im-Mațtah dialects almost all nouns take nūnation, with the exception of nouns with the vowel scheme $a f^{\prime} a l, f a l a \bar{y}$, and nouns with the feminine ending - $a$ h or -eh (i.e. the ending * ${ }^{*} a t$ ) and nouns that end in -i. Some of the examples he cites are:

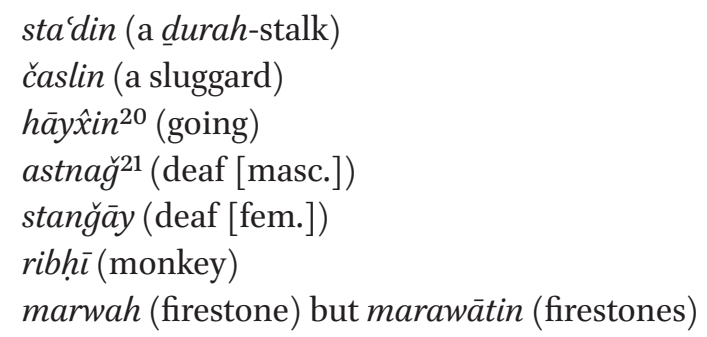

The $a f^{\prime} a l$ and $f a^{\prime} l \bar{a} y$ patterns that do not take nūnation are obviously related to the Classical Arabic diptotic af'alu and $f a^{\prime} l \bar{a}^{\prime} u$, and the absence of the nūnation on nouns of this type must be attributed to their original diptotic and therefore nūnation-less form. The fact that the feminine ending, likewise, does not take nūnation is a clear indication that in this dialect, feminine nouns were treated as diptotes as well.

A similar distribution is found by Greenman: af'al forms and feminine nouns do not take the $-u$ indefinite marker. ${ }^{22}$

Prochazka ${ }^{23}$ observes a rather more complex situation for the dialect of BalQarn. The indefinite marker has two allomorphs $-\bar{u} / u$ in pause and -in in nonpausal position. The feminine ending -ah/-eh does not take the $-\bar{u} / u$ ending, nor does the $a f^{\prime} a l$ elative, the $a f^{\prime} a l$ for physical defects and colours, however,

\footnotetext{
17 Joseph Greenman, "A Sketch of the Arabic Dialect of the Central Yamani Tihāmah," Zeitschrift für Arabische Linguistik, 3 (1979), p. 6 o.

18 Theodore Prochazka, Jr. "Gleanings from the Southwestern Saudi Arabia," Zeitschrift für Arabische Linguistik, 19 (1988), p. 47-49.

19 Behnstedt, Die Dialekte, p. 209.

20 All transliterations that differ from the standard Arabica system refer to specific phonemes proper to Yemeni dialects and follow the romanization conventions explained in Behnstedt's Die Dialekte. In the dialect of im-Mattrah $\hat{x}$ corresponds to Classical Arabic š. Behnstedt describes it as ein retroflexer ich-Laut. Behnstedt, Die Dialekte, p. 9 f.

21 In the dialect of im-Mațtah st corresponds to Classical Arabic ș. It functions as a single root consonant. Behnstedt, Die Dialekte, p. $7 \mathrm{ff}$.

22 Greenman, "A Sketch of the Arabic Dialect of the Central Yamani Tihāmah."

23 Prochazka, "Gleanings from the Southwestern Saudi Arabia," p. $47 \mathrm{ff}$.
} 
does take this ending. ${ }^{24}$ In non-pausal position the feminine nouns seem to also take the indefinite marker -in. Prochazka also cites free variation in pause between forms with and without -in:

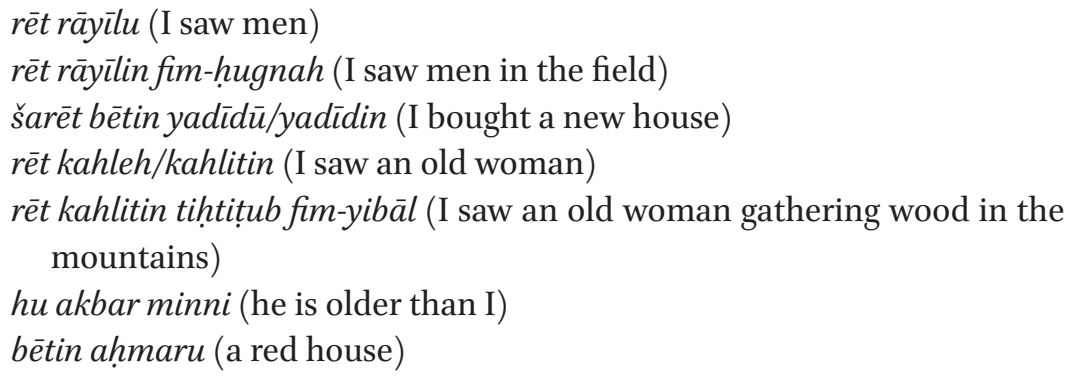

The situation attested in the dialects described by Behnstedt and Greenman likely preserves the original distribution. The fact that in pause nouns can optionally take the non-pausal indefinite marker -in should be considered to be indirect evidence that the -in ending is spreading to places it was previously not present. It seems likely, that this spread of the -in ending also explains its presence on feminine endings in non-pausal position.

From this evidence, it is clear that in these dialects the feminine endings were originally diptotes without nūnation. ${ }^{25}$ This must then be considered to be evidence that in some dialects of Arabic, the feminine ending -at was originally diptotic, and as such it becomes likely that also in the language of the Qurānic Consonantal Text the feminine ending was diptotic, which would perfectly explain the reflex of the indefinite accusative.

In Classical Arabic, despite the triptosy of the feminine ending, the orthography follows the Quraanic Consonantal Text and writes the indefinite accusative with $\alpha$. Classical Arabic orthography seems to have derived the orthographical rule that the feminine ending should be spelled $\alpha$, regardless of pronunciation. Although there are orthographic differences between the orthography of the Qurānic Consonantal Text and Classical Arabic; Classical Arabic still largely follows the old orthography in that it does not spell i'rāb and nūnation.

24 Prochazka also says that the feminine ending - $a$ (original alif maqșüra) does not take this ending, but does not cite any examples in his overview, but he mentions miza (goats) < *mi'zä (ibid., p. 49).

25 In the vast majority of other dialects, it is of course possible that the feminine ending ${ }^{*}$-at was also diptotic, but it is simply impossible to see it, as they have not retained nūnation or case to confirm it. 


\title{
Motivation for Diptotic Feminines
}

It is difficult to imagine how originally triptotic feminine nouns would have become diptotic in both the language of the Qurānic Consonantal Text and the Arabic dialects that we have discussed, either as individual innovations or as a shared innovation. Diptotes make up a small and rather erratic group of nouns within the Arabic language, and it is difficult to imagine how this would have spread to all feminine nouns. It is more attractive to suppose that the feminine ending * -at was originally diptotic, and only later became triptotic.

Where nouns with the ending -at are always triptotic in the Classical Arabic grammar, this is not the case for proper names with this ending. If a proper name ends in the feminine ending -at it is always diptotic. This is even true when it is suffixed to a stem which in the masculine form would normally be triptotic. Most proper names without the feminine ending are diptotic, but the ones that are triptotic can be summed up by the following criteria: ${ }^{26}$

\author{
Stem shape CvCC: Amrun, Zaydun, Di'bun \\ Diminutives: Zuhayrun, Kutayyirun \\ Participles: Muhammadun, Hārițun, Muslimun, Hāni’un
}

These three categories become diptotic when the feminine suffix is attached:

\author{
CvCCat: Sawdatu, Hafșatu, Ramlatu \\ Diminutives: Fuțaymatu \\ Participles: Fāțimatu, 'A'išatu, Amìnatu, Hādiǧatu
}

The only thing about these names that make them diptotic is the feminine ending. Therefore, there seems to be something about the feminine ending that is associated with diptosy.

One might consider the possibility that the diptosy of the feminine ending developed in this category of proper names, and spread to all feminine nouns. It is, however, difficult to motivate how such a marginal characteristic of proper names would come to be spread analogically to all nouns with the feminine suffix in general.

A spread in the opposite direction is much easier to motivate. Feminine common nouns that are regularly derived from masculine nouns may easily have received a triptotic pattern analogous to that of the masculine form. Because proper names with the feminine ending do not have the same morphological

26 Fischer, A Grammar of Classical Arabic, § 153. 
relation to triptotic masculine names, the same spread did not affect them. The diptotic feminine ending of the proper names is thus to be considered a linguistic vestige in Classical Arabic of the original diptotic nature of the feminine ending - at. The retention of this vestige was perhaps aided by the diptosy of many other proper names.

Besides the feminine ending - $a$, Arabic has two other feminine endings, $-\vec{a}^{\prime}$ and $-\bar{a}$ (orthographically $、<{ }^{*}-a y u$ ). Both of these feminine endings are also diptotic. ${ }^{27}$ This reveals a general pattern of diptosy being associated with feminine endings. These facts therefore are most easily explained through a reconstruction of Proto-Arabic where all three feminine endings, *-at, *-ay and *-āy were diptotic.

Reconstructing original diptosy for the feminine ending in Proto-Arabic, however, raises problems within its broader Semitic context. The two other Semitic languages that show signs of diptosy, Ugaritic and Ancient South Arabian, appear to simply have triptotic flection for feminine ending - $(a) t$.

Ugaritic, like Arabic, has a diptotic flection. ${ }^{28}$ This flection mostly concerns personal names with an $-\bar{a} n$ suffix ( $c f$. the diptotic fa làn adjectives in Classical Arabic ${ }^{29}$ ). Feminine nouns, however, are consistently triptotic. ${ }^{30}$ Ugaritic, like Arabic, has retained diptotes in names, but there is no direct evidence that feminine names remained diptotic.

In Sabaic, the vast majority of the nouns in the absolute state have mimation, the structural equivalent to Arabic nūnation, this includes feminine nouns with the feminine ending $-t$. However, Sabaic names, masculine or feminine, generally lack mimation, which is presumably a reflection of the same tendency to diptosy that we find in Arabic proper names. ${ }^{31}$

A full account of the place of diptotic feminines within Proto-Semitic requires further research that falls outside of the scope of this paper. Discussion of this topic, however, will have to be conducted with the likely possibility in mind that in Proto-Arabic all feminine endings were originally diptotic.

\footnotetext{
$27 \quad$ Ibid., $§ 153$ b and note 1.

28 Josef Tropper, Ugaritische Grammatik, Münster, Ugarit-Verlag ("Alter Orient und Altes Testament", 273), 2000, p. $304 \mathrm{ff}$.

29 Fischer, A Grammar of Classical Arabic, § 119.

30 Tropper, Ugaritische Grammatik, p. 302 ff.

31 Alfred Felix Landon Beeston, A Descriptive Grammar of Epigraphic South Arabian, London, Luzac \& Co, 1962, § 27.4.
} 


\section{Conclusion}

In this paper, I propose that the nouns with the feminine ending -at in the language of the Qur'annic Consonantal Text behave like diptotes and that this behaviour is paralleled in several dialects still spoken today in the Yemen and Saudi Arabia. It has been argued that this situation likely goes back to ProtoArabic, as it is difficult to imagine how these dialects acquired diptotic feminine endings if they were originally triptotic. An open question is how this information should be interpreted in light of the other Semitic languages.

The diptotic value of the feminine ending stands in stark contrast with the triptotic feminine endings as found today in Qurānic recitations. This suggests that there is a tangible linguistic disconnect between the language of the Qur'ānic Consonantal Text and the reading traditions. I leave the implications of this observation to scholars of Islamic studies. 